\title{
Analysis of the relationship between innovation, stock market and economic growth in the case of China
}

\author{
Análise da relação entre inovação, mercado acionário e crescimento \\ econômico no caso da China
}

\author{
Gelson Eduardo Dalle Nogare ${ }^{1}$ \\ Jéferson Réus da Silva Schulz ${ }^{2}$ \\ Franco da Silveira ${ }^{3}$ \\ Janis Elisa Ruppenthal ${ }^{4}$
}

\begin{abstract}
The objective of this is study is to analyze the behavior and the relationship between the stock market and the macroeconomic developments, based on technology development, through the variables that influence these rates to China, under the hypothesis that a decrease in stock prices may reflect in bad news regarding to technological progress and long-term economic growth. As reference to the innovation question, the study considers The Global Innovation Index (GII) based in China's position note; for the economic growth question, the reference is the Chinese real GDP; and for the capital market question, it is considered the Chinese stock exchange index (SSE Composite). For the analysis and correlation of these variables it was used the calculation of the Pearson's correlation coefficient " $r$ ". The results suggest that the performance of the capital market cannot be an economic indicator for China's case, not presenting evidence that its performance is related to those of the real economy and the technological innovation.
\end{abstract}

Keywords: Innovation. Economic Growth. Stock Market. Global Innovation Index.

\section{Resumo}

O objetivo deste estudo é analisar o comportamento e a relação entre o mercado de ações e o desenvolvimento macroeconômico, com base no desenvolvimento tecnológico, através das variáveis que influenciam essas taxas para a China, sob a hipótese de que uma queda nos preços das ações pode refletir em más notícias em relação ao progresso tecnológico e ao crescimento econômico em longo prazo. Como referência, para o quesito inovação, o estudo considera o Índice de Inovação Global (GII), com base na nota de posicionamento da China; para o quesito crescimento econômico, a referência é o PIB real chinês; e, para o quesito mercado de capitais, é considerado o índice de bolsa de valores chinesa (SSE Composite). Para a análise de correlação dessas variáveis foi utilizado o cálculo do coeficiente de correlação de Pearson "r". Os resultados sugerem que o desempenho do mercado de capitais não pode ser um indicador econômico no caso da China, não apresentando evidências de que seu desempenho esteja relacionado com o da economia real e da inovação tecnológica.

Palavras-chave: Inovação. Crescimento econômico. Mercado de ações. Índice de Inovação Global.

\section{Introduction}

The approaches on economic growth consider the innovation relevance as an essential component to stimulate such process. Thus, macroeconomic models highlight the presence of the technology variable

Mestre em Engenharia de Produção pelo Programa de Pós-Graduação em Engenharia de Produção da Universidade Federal de Santa Maria. Brasil. Afiliação: Universidade Federal de Santa Maria. Lattes: http://lattes.cnpq.br/4545241026375581 Email: gdalenogare@gmail.com

2 Mestrando em Engenharia de Produção pelo Programa de Pós-Graduação da Universidade Federal de Santa Maria. Brasil. Afiliação: Universidade Federal de Santa Maria. Lattes: http://lattes.cnpq.br/9358462344127909 Email: jefersonschulz@gmail.com

3 Mestrando em Engenharia de Produção pelo Programa de Pós-Graduação em Engenharia de Produção da Universidade Federal de Santa Maria. Brasil. Afiliação: Universidade Federal de Santa Maria. Email: franco.da.silveira@hotmail.com

4 Doutora em Engenharia de Produção pela Universidade Federal de Santa Catarina e Professora no Programa de Pós-Graduação em Engenharia de Produção da Universidade Federal de Santa Maria. Brasil. Afiliação: Universidade Federal de Santa Maria. Lattes: http://lattes. cnpq.br/7074971060238600 Email: janis.rs.br@gmail.com 
as vital to transform the traditional production factors, capital and labor, into products. Are also diverse the economic growth approaches that emphasize the role played by the financial markets as an element that contributes to optimize the allocation of financial resources in an economy, generating thus a substantial improvement in the performance of macroeconomic indicators, such as Gross Domestic Product (GDP) (Hicks, 1969; Schumpeter, 1982; Romer, 1986; Lucas, 1988).

Because of this, developed and emerging countries have been paying attention to the relationship between the financial sector development and the economic growth linked to the role played by innovation in this scenario. Mankiw (2011) emphasizes that this relationship becomes even more dispersed when trying to analyze the relationship and the intrinsic role of innovation as a driving mechanism of stock market performance and hence of the real economy. As the author said, economists believe that this relationship could reside in the hypothesis that a decrease in stock prices could be reflecting in negative news regarding technological progress and long-term economic growth. As a result, the author proclaims that the natural level of production and therefore the aggregate supply of goods and services tend to grow more slowly in the future than previously expected.

Thus, the relationship between stock market, real economy and changes in the technological level cannot be unnoticed by economic policymakers. This is because data on the stock market often anticipate changes in real GDP since the data on stock quotes is available almost instantaneously and is also easily accessible, unlike the GDP data of countries.

China has sought to adapt to an economy oriented towards innovation since its accession to the World Trade Organization (WTO) in 2001. Currently, the country stands as one of the fastest growing economies in the world and one of the countries with highest global competitiveness (Wonglimpiyarat \& Khaemasunun, 2015). In this sense, because China is a powerhouse in the global economy and have a significant impact on the international economy due to its business relations with other countries, it is considered appropriate to analyze the relationship between innovation, stock market and economic growth in this country, given the economic influence it exerts worldwide.

It should be noted that the Chinese economy has stood out compared to the other emerging and developing economies, showing high growth rates in the post-reform period, which began in the late 1970s (Vieira, 2006). Several aspects are pointed out as factors in this scenario of prosperity, such as high investment rates, greater commercial and financial opening, rigid exchange rate regime, investment in human capital, among others (Veira, 2006). The model of Chinese economic growth is based on investments and the external sector (Mendonça, 2015).

Still on vigorous Chinese economic growth, we highlight the interconnected performance of various factors, such as geographical, historical, political and economic (Nonnenberg, 2010). Indeed, it is reasonable to imagine that each of them made a significant contribution to the performance of the Chinese economy over the past 30 years (Nonnenberg, 2010). In addition, it is important to emphasize that China's influence on the international economy is largely due to China being an economic power and an industrial power in technology-intensive sectors, as well as a power in sectors traditional and political-military (Carmo, 2011).

In this context, our research problem lies in discussing whether the stock market can serve as evolution predictor of economic growth and technological innovation and be used as an economic indicator for China's case. The aim of this study is grounded on analyzing the behavior and the relationship between the stock market and the macroeconomic developments, based on technological development, testing the hypothesis that a decrease in stock prices may reflect in bad news regarding to technological progress and Chinese long-term economic growth.

The relevance of this article has its pilar on the possibility to verify how the variables of innovation, stock market and economic growth are related. This type of analysis allows us to understand, for example, the impact of innovation on the stock market and on the economic growth of countries. The case of China is analyzed as it is a world power that exerts influence over other countries.

One of the main reasons for this type of analysis is that innovative companies, for example, when making high investments in science and technology, generate jobs and income. This also increases their market value, providing financial return. In the economic system, this is reflected in higher rates of economic 
growth. In this way, identifying the relationship between innovation, stock market and economic growth is important because it can be used as an incentive tool for innovation policies.

\section{Theoretical framework}

\subsection{Technological innovation and The Global Innovation Index (GII)}

Innovation is an essential feature of human progress and is also inherent in the economic growth. First of all, innovation makes the products more competitive, allowing companies to introduce them into a wider range of markets, and enabling the triggering of new enterprises opening. Thus, firms need to innovate continuously and rapidly to survive in today's competitive and global markets (Badillo \& Moreno, 2015). In second place, theoretical empirical approaches reinforce the importance of innovation processes by intrinsic factors, which encourage the disseminated introduction of innovation in companies. (Schumpeter, 1951; Goldsmith, 1969; Lucas, 1972; Romer, 1990; Mankiw, 2011; Galindo \& Picazo, 2013).

Schumpeter (1951) introduced the term "creative destruction", which suggests that the driving force of the process of economic growth would come through the entrepreneurial figure, with an idea for a new product, a different way to make an old product or some other form innovation. His theory is based on the premise that when entering the market, the entrepreneur's company will hold some monopoly power on its innovation. The entry of this new company is positive for the consumer, who will have a wider range of options, however, will be a negative factor for other companies due to their difficulty to compete with the new entrant. Thus, in case an organization present a radical and disruptive innovation, this will involve the removal of competitors from the market, featuring thus a permanent process of constant renewal, since that the new entrepreneur's company will enjoy a high profitability level until that his product be outbid by another entrepreneur, with the generation of a new idea.

It is widely accepted that innovation is an essential component for the growth of output and productivity, as it allows advantages in technologies and greater flows of information (Organisation for Economic Cooperation and Development [OCDE], 2005). In this sense, Mankiw (2011) argues that the long-term economic growth is the only determinant of economic prosperity of a country and that high standards of living come from the sustained growth of productivity, which requires constant improvement of economy as a whole. Therefore, the author stresses that the most important goal to be followed is the creation of public policies that make grow the technological progress level of a nation.

The generation, exploitation and diffusion of knowledge are fundamental to economic growth, development and well-being of nations, so that it is essential to have better innovation measures (OCDE, 2005). It is worth noting that innovation is an ongoing process through which companies constantly make changes in products and processes and seek for new knowledge, what causes it difficult to be measured, since it is a dynamic activity, not static (OCDE, 2005).

The Global Innovation Index (GII) is promoted by Cornell University and The Business School for the World (INSEAD) along with the World Intellectual Property Organization (WIPO), a specialized agency of the United Nations best known by its initials. The GII report consists in a ranking of innovation capabilities of the world economies, which recognizes the fundamental role of innovation as a driver for economic growth, prosperity and the need for a wide horizontal viewing of innovation applicable to both developed and emerging economies.

Currently, GII is set as the main reference between the innovation indexes and also serves as a valuable benchmarking tool to facilitate the dialogue between public-private institutions. GIl gathers data from more than 30 sources, covering a broad spectrum of innovation drivers and results, privileging concrete data on qualitative assessments. The index has as its main objective to achieve the improvement of the "path" to a better understanding of the innovation measurement. In order to achieve this, the GII starts at the identification of targeted policies, in which good practices and other levers allow the emergence of innovation.

For its last edition, The Global Innovation Index 2014, the report was based in two sub-indexes, an innovation input sub-index and an innovation output sub-index, each built around fundamental pillars. In the input sub-index there are five pillars that describe and capture the elements of the national economy, 
identifying innovative activities: i) institutions; ii) human capital and research; iii) infrastructure; iv) market sophistication; and v) business sophistication. In the output sub-index there are two pillars to capture the actual evidence of innovation results: i) knowledge and technology output; and ii) creative outputs.

Each pillar is divided into sub-pillars and each of these consists of individual indicators (81 in all). The sub-pillar scores are calculated as the weighted average of the individual indicators, and the pillar scores are calculated as the weighted average of the sub-pillar scores. Four measures are then calculated: i) the innovation input sub-index, which represents the simple average of the scores of the first five pillars; ii) the sub-index of innovation output, which represents the simple average of the two last pillars; iii) the general GII, which represents the simple average of the input and output sub-indexes; and iv) the innovation efficiency index, which represents the relation between the two innovation sub-indexes (output and input).

\subsection{Some theoretical approaches on economic growth}

From the macroeconomic perspective, a typical model of economic growth starts from an aggregate production function with the following format: $Y=f(K, N, t)$, where $Y$ indicates the real product, $K$ the capital stock, $\mathrm{N}$ the force work time and time (Simonsen \& Cysne, 2009). The time variable describes the evolution of the production function with technological progress (Simonsen \& Cysne, 2009). In addition, it is assumed that $Y$ is a growing (or at least not decreasing) function of capital, labor, and technology, since capital and labor contribute to the production and the goal of engineering is to enhance the productivity of available factors (Simonsen \& Cysne, 2009). There are also natural resources, embedded in the capital stock, allowing the aggregate production function to be homogeneous in K and N (Simonsen \& Cysne, 2009).

In economic literature there is a wide range of models that approach economic growth. Among them there are the endogenous growth models. These models allow further deepening to the analysis of the relationship between financial development, more specifically the performance of the capital market, and economic growth (Romer, 1986; Lucas, 1988). In this context, Romer (1986) and Lucas (1988) sought to understand and describe, over the years, what is the cause and effect relationship between economic growth and financial development.

Other approaches, such as that of Schumpeter (1982), introduce the technological innovation component in this discussion. In Schumpeter's (1982) approach the basic premise for the development of an economy considers the essential role of technological innovation. The author also argues that there is a propitious relationship between financial and capital markets development and the economic growth. In view of this, he defends that a developed financial sector leads to a natural raise of GDP.

Solow (1956), with his exogenous growth model, argues that the long-term economic growth depends on the junction between the factors of capital production and labor and of the technology, whose function is to transform the capital and labor into products. Thus, according the author, the GDP grows as the production factors increase or when the economy becomes more efficient in transforming these inputs into products constituted by goods and services.

Later approaches emphasize the role of the capital market regarding the process of economic growth. Considering that it is not only technological innovation that contributes to economic growth, Hicks (1969) argues that the emergence of the capital market allows the mobility of great resources and the introduction of technology in industrial production, resulting in a sharp economic expansion.

With the theory of endogenous growth, Romer (1986) and Lucas (1988) argue that economic growth is the result of higher levels of savings and investment. In supporting the same hypothesis of Romer (1986), Lucas (1988) highlights the need to enumerate and identify all the different variables (not just the financial variables) for an economic model to be relevant.

Indeed, if the development of the financial sector is quantified by the level of funding capacity and the stock market, financial markets anticipate economic growth. This perception is due to the fact that the stock market capitalizes companies and hence evidences investment opportunities, directing the resources to 
more attractive sectors, which results in a "natural selection", predisposing an anticipation of the economic future (Lucas, 1988).

\section{Research method}

\subsection{Data source}

The study made use of statistical correlation as a tool in order to verify, in the case of China, if the financial sector precedes economic growth, or if it is the real sector that drives the evolution and development of the financial sector. After the structuring of the database, the variables were transferred to the statistical software Statistica $\AA^{\circ}$. At this stage, we started an investigation on the correlation between the innovation indicator (Global Innovation Index), the product of the economy (real GDP) and the data from the stock exchange (Stock Index). Data were collected taking into account a period of five years, between 2010 and 2014.

The item innovation has as a reference the Gll based on the global positioning note of China. For data relating to macroeconomic performance, the reference is the real GDP based on the figures provided by the Organization for Economic Cooperation and Development, expressed in current U.S. dollars. For the capital market, it was used the main stock index of the Chinese stock market, Shanghai Stock Exchange Composite Index (SSE Composite), being considered the amount expressed on the last day of trading of each year, as shown in Table 1.

Table 1 - Data collected for analysis

\begin{tabular}{cccc}
\hline Years & GII & GDP & SSE Composite Index \\
\hline 2010 & $43^{0}$ & $5.930 .502 .270 .313,00$ & $2.808,08$ \\
2011 & $29^{0}$ & $7.321 .891 .954 .608,00$ & $2.199,42$ \\
2012 & $34^{0}$ & $8.229 .490 .030 .100,00$ & $2.269,13$ \\
2013 & $35^{0}$ & $9.240 .270 .452 .047,00$ & $2.115,98$ \\
2014 & $29^{\circ}$ & $9.924 .050 .465 .498,48$ & $3.234,68$ \\
\hline
\end{tabular}

Source: Based on survey data.

In China, the SSE Composite is the main stock index of the Shanghai Stock Exchange. This index consists of all shares listed on the Shanghai Stock Exchange (SSE). The base date considered for the calculation of the SSE Composite Index is December 19, 1990. The base price starts with 100 (one hundred) points, equivalent to total capitalization of Shanghai Market on that date The first trading day of the Chinese index took place on July 15, 1991. As the assets listed in the Shanghai Stock Exchange are divided into series of $A$ and $B$ shares, there is a specific index for each of these series: SSE A Share Index and SSE B Share Index. The SSE Composite Index is equal to the sum of the two indexes (SSE, 2015).

\subsection{Method of data analysis}

The study has as its reference the Pearson's simple linear correlation coefficient, represented by the letter "r". If the value of " $r$ " is +1 , the correlation is positive and perfect, which means that high values on a variable correspond to high values on the other variable, that is, they grow together. If the value of " $r$ " is -1 , the correlation is negative and perfect, which means that high values on a variable correspond to low values on the other one, that is, as one increases, the other decreases. The closer the value of " $r$ " is to zero, the smaller is the evidence of correlation among the variables; and the closer the value of " $r$ " is to +1 and -1 , the bigger is the correlation between the variables.

For didactic purposes of this study, it was used as a fundamental rule that the Pearson's "r" correlation coefficient would have a 95,00\% significance level, i.e., it would be statistically significant at the $p<0,05$ ( $p$-value). Besides that, it was also considered that its acceptance should have a strength of association 
established as "very strong", that is, set between the covariation intervals $\pm 0,91$ and $\pm 1,00$, as explained in Table 2.

Table 2 - Correlation coefficient and strength of association between the variables

\begin{tabular}{cc}
\hline Pearson's correlation coefficient ("r") & Strength of association \\
\hline $0,91- \pm 1,00$ & Very strong \\
$\pm 0,71- \pm 0,90$ & Strong \\
$\pm 0,41- \pm 0,70$ & Moderate \\
$\pm 0,21- \pm 0,40$ & Weak, but set \\
$\pm 0,01- \pm 0,20$ & Very weak, almost imperceptible \\
\hline
\end{tabular}

Source: Adapted from Hair, Black, Babin, Anderson and Tatham (2005).

The calculation of the Person's " $r$ " correlation coefficient took place to determine if there is a consistent and systematic relationship between the variables innovation (The Global Index of Innovation - GII), stock market performance (Stock Exchange Index - SSE Composite), and economy performance (Macroeconomic Variation - real GDP). However, it is important to understand that if there is such a relationship, this is not necessarily causal, that is, one cannot say that one variable is the cause of the other.

Thus, the understanding of the other elements, such as the presence, the nature, and the direction of relationships and the strength of association contributed to a better understanding of the relationship between the variables. The steps for analyzing the "r" correlation coefficient between the variables defined for the study and the subsequent graphical interpretation are described below: i) analysis of the relationship between the global index innovation (variable "Y") and the stock exchange index (variable "X"); ii) analysis of the relationship between the stock exchange index (variable " $Y$ ") and the real GDP (variable " $X$ "); iii) analysis of the relationship between real GDP (variable "Y") and the innovation index (variable "X").

The correlation coefficient is a symmetrical measure of association, i.e., the correlation between $Y$ and $X$ is the same as the correlation between $X$ and $Y$, independently of which of the variables is dependent or independent (Hair et al., 2005). Accordingly, the "r" correlation coefficient will determine if there is a direct linear relationship, or reverse, between $\mathrm{Y}$ and $\mathrm{X}$, indicating the influence of $\mathrm{Y}$ in $\mathrm{X}$ and vise-versa.

This study aims to verify the relationship between the stock market and macroeconomic evolution, based on technological development. It is considered that the statistical correlation implies an instrument of analysis capable of fulfilling this objective. Therefore, a statistically significant relationship between the variables and within the covariation intervals established as criteria to evaluate the strength of this relation can be inferred whether or not there is a linear association between innovation, stock market and total product of the economy. However, it is important to emphasize that, once such association is observed, it does not suggest that one variable causes the other, since the correlation coefficient does not presuppose a cause and effect relationship.

\section{Results and discussion}

\subsection{Analysis of the correlation coefficients}

Table 3 shows the correlation matrix between the variables considered in the study as a way to verify, in the case of China, if the financial sector precedes the country's economic growth, or if it is the real sector that drives the evolution and development of the financial sector. Thus, Table 3 shows the correlation coefficient between the global innovation index (GII) and the SSE Composite's stock exchange index, the correlation coefficient between the the SSE Composite's stock exchange index and the real GDP, and the coefficient correlation between real GDP and the global innovation index (GII). 
Table 3 - Correlation matrix for China

\begin{tabular}{cccc}
\hline Variables & GII & GDP & SSE Composite \\
\hline GII & - & $-0,651544$ & 0,019773 \\
PIB & $-0,651544$ & - & 0,143263 \\
SSE Composite & 0,019773 & 0,143263 & - \\
\hline
\end{tabular}

Source: Based on survey data.

Table 3 shows that there is a correlation coefficient of order $r=0,019773$, with positive direction, between the innovation index (GII) and the SSE Composite's stock exchange index. Thus, it is possible to infer that there is no presence of consistent and systematic association between these two variables, since the found association strength is described as "weak, almost imperceptible". Therefore, the probability of knowing and predicting the behavior of a variable does not allow us to know and predict the behavior of the other variable.

Through the analysis of the relationship between SSE Composite's stock exchange index and the real GDP is proved the existence of a correlation coefficient, also with positive direction, of order $r=0,143263$. As with the previously described relationship, the likelihood of knowing and predicting the behavior of a variable does not allow us to know and predict the behavior of the other variable.

Regarding the comparison between the real GDP and the GII, is verified the existence of a negative direction of correlation coefficient of order $r=-0,651544$. The result indicates that there is no presence of systematic and consistent association between these two variables. Although the association strength force is described as "moderate", the probability of knowing and predicting a variable behavior does not allow us to know and predict the behavior of the other variable.

The data reveals a complete lack of consistent and systematic relationship between the variables considered in the study. In view of this, it is possible to safely infer that none of the relationships complies with the criteria established for this research, rejecting the hypothesis of the study, since changes in stock index (SSE Composite) would not be reflecting consistently and systematically in variations of the innovation levels (GII) and hence in the macroeconomic performance (real GDP).

Complementarily to the information observed by calculating the correlation coefficient, the scatter diagram provides additional information to support the decision to accept or reject any relationship between the variables. So first it was made the analysis of the data according to the relationships defined above, that is: the correlation between the innovation index (GII) and the stock exchange index (SSE Composite), followed by the analysis of the correlation between the stock exchange index (SSE Composite) and the real GDP and, finally, the correlation between real GDP and the innovation index (GII), as shown in Figures 1, 2, and 3.

Figure 1 - Scatter plot for the innovation index (GII) in function of the stock exchange index (SSE Composite)

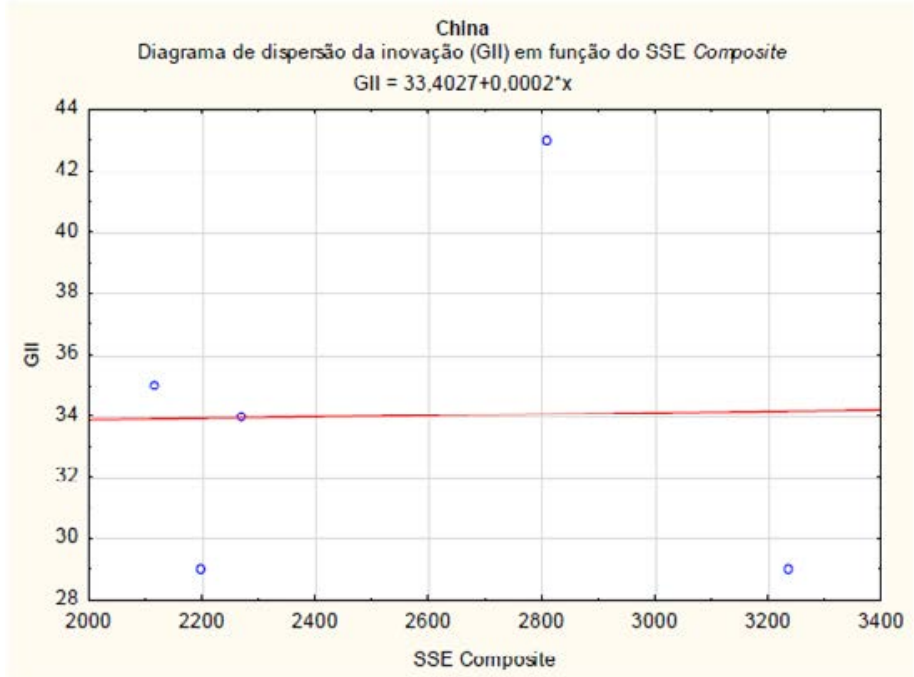

Source: Survey data. 
The scatter plot in Figure 1 shows the data on innovation index (GII) in function of the stock exchange index (SSE Composite). Through its analysis and visualization, it is verified that the points are randomly distributed around the line, showing no apparent relationship or association between variables. Thus, it is possible to infer that there is not a predictable or identifiable pattern for the points. This suggests that knowing the $Y$ and $X$ values is not enough in this analysis, so that there is not a consistent and systematic relationship between the innovation index (GII) and the stock exchange index (SSE Composite), as well as there is little or no shared covariation between the variables. In summary, the scatter plot corroborates the evidence of calculating the correlation coefficient, indicating that this relationship actually does not meet the criteria of the presence of statistical significance and strength of association between the innovation index (GII) and the stock exchange index (SSE Composite).

Figure 2 - Scatter plot for the stock exchange index (SSE Composite) in function of the real GDP

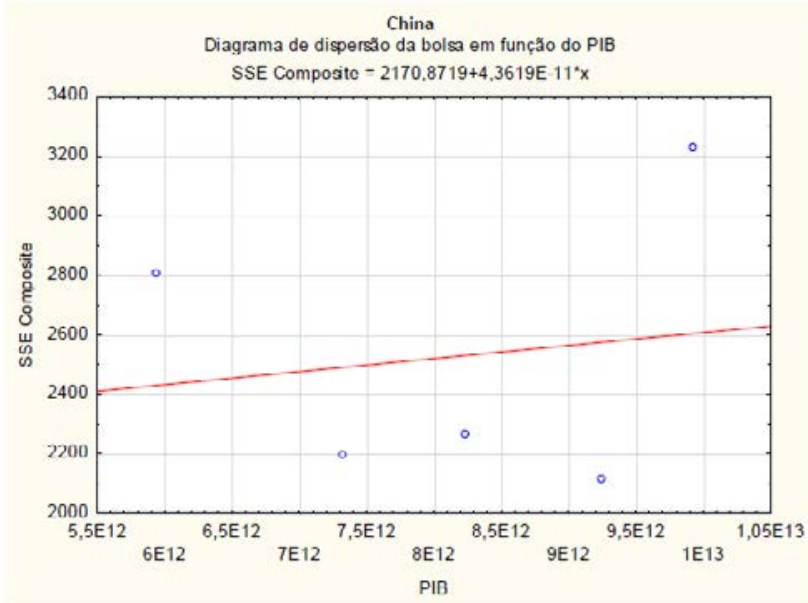

Source: Survey data.

The scatter diagram in Figure 2 shows the data on the stock exchange index (SSE Composite) in function of the real GDP. Through its analysis and visualization, it is verified a framework similar to the one of the previous analysis, in which the points are randomly distributed around the line, showing no relationship or apparent association between the variables, which indicates the absence of a predictable or identifiable pattern for the points. This suggests that knowing the $Y$ and $X$ values is not enough in this analysis, so that there is no coherent and systematic relationship between the stock exchange index (SSE Composite) and the real GDP, as well as there is little or no shared covariation between the variables. Thus, the scatter plot corroborates the evidence of calculating the correlation coefficient, indicating that this relationship actually does not meet the criteria of the presence of statistical significance and strength of association between the stock exchange index (SSE Composite) and the real GDP.

Figure 3 - Scatter plot for the real GDP in function of the innovation index (GII)

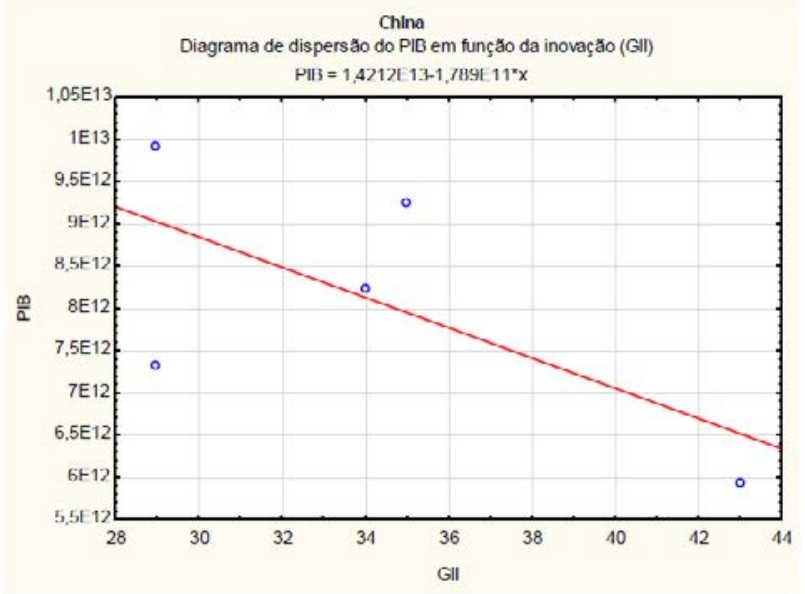

Source: Survey data. 
In Figure 3, the scatter plot displays the data for the real GDP in function of the innovation index (GII). Its analysis and visualization help determine a framework similar to the one of the previous analysis, in which the points are randomly distributed around the line, showing no apparent relationship or association between variables. This indicates that there is not a predictable or identifiable pattern for the points and that knowing the values of $Y$ and $X$ is not enough in the analysis, suggesting the absence of consistent and systematic relationship between the real GDP and the innovation index (GII), as well as little or no covariation is shared between the variables. Thus, the scatter plot contributes to the evidence of calculating the correlation coefficient, suggesting that this relationship actually does not meet the criteria of the presence of statistical significance and strength of association between the real GDP and the innovation index (GII).

It is observed that the relationship between innovation, stock market and economic growth is low for the standards adopted in this research. The results demonstrate the inexistence of a coherent and systematic relationship between these variables. This allows to infer that the variations of the stock index (SEE Composite) do not reflect in the variations of the level of innovation (GII) and the macroeconomic performance (GDP) in the case of China.

Chinese incentives for innovation follow the changes in policy orientation, with a number of changes over the years, where the Chinese government has gradually shifted its role from direct R\&D provider to the most important strategic planner and provider of science and basic research (Araújo, 2013). The current strategy of Chinese innovation consists of an orientation of the innovation policies focused on the innovative capacity of the firm, and the public research system is still dominant in relation to the allocation of public resources (Araújo, 2013). As the main result of this innovation policy, with project-based R\&D funding rather than universal and horizontal funding, China is characterized as the country receiving the most direct foreign investment (FDI) in the world (Araújo, 2013).

The Chinese economy has experienced vigorous and steady growth over the last three decades, highlighting the intense increase in productivity and expansion of production capacity, both of which are the result of the high levels of investment observed in the country (Mendonça, 2015). In the field of the Chinese financial sector, finances affect all economic spheres and constitute the fundamental lever to promote economic development as well as a structural transformation (Burlamaqui, 2015). It should be stressed that China has been building a robust and comprehensive strategy within the framework of a state-led and globally oriented financial governance model (Burlamaqui, 2015), in which the Chinese financial system counts on the participation of bodies that regulate and oversee the capital market and the insurance segment (Deos, 2015).

The main feature of the Chinese stock market is related to its size and representativeness. Indeed, China's stock market is characterized as being considerably small and even irrelevant since it would not account for more than $5,00 \%$ of the wealth of Chinese households while the majority of its investors, about $80,00 \%$, would be inexperienced individuals who would follow rumors when making decisions, unlike the professional investors of the European and North American markets (Silva, 2015).

It should also be pointed out that, regarding China's recent growth strategy, it points to an inflection in the conduct of economic policy, previously driven by advances in foreign trade (Silva, 2015). In this context, the authorities intend to rebalance the country's economy through moderate growth and a domestic market (Silva, 2015).

\subsection{Comparison with similar studies}

Studies such as that of Kuznets (1966) point out that the economic growth of countries such as England, the United States and Germany occurred simultaneously with population growth and per capita income growth, permeated by significant technological advances. In addition, public policies that increase the level of technological progress of a nation should be the most important goal to be followed, since they guarantee a country's economic prosperity and higher standards of living (Mankiw, 2011).

In analyzing data from 35 countries over several decades, Goldsmith (1969) concludes that there is a strong relationship between economic growth and the development of the financial system. Similarly, Shaw (1973) shows that countries with higher economic growth have evolved financial markets. For Modigliani 
and Miller (1958), there is no obvious relationship between financial development and economic growth. For these authors, financial markets are independent of the economy and the way companies obtain financing should not be taken into account.

Shen and Lee (2006) investigated the relationship between stock market performance and the performance of development banks in the process of economic growth in 48 countries. The authors concluded that an efficient and developed capital market has significant effects on economic growth.

Cooray (2010) examined the relationship between stock market and economic growth in the stock market of 35 developing economies. Analyzing three proxies (market capitalization, market liquidity and turnover rate), the author noted the existence of a strong relationship between those and economic growth. The author's study suggests that the stock market is important in determining the economic growth of the countries analyzed in the long run.

Zhang, Wang and Wang (2012) analyzed the dynamic relationship between financial development and economic growth in 286 Chinese cities during the period 2001 to 2006 . The results achieved by the authors indicate a positive association between traditional financial performance indicators and economic growth, contrary to the assumptions that a state-run banking sector, such as China, hampers economic growth.

Ahmed and Mmolainyane (2014), in a study in Botswana, explored the impact of financial integration on the country's economic growth from 1974 to 2009. The results indicate that there is no direct, robust and statistically significant association between the development of the financial system and economic growth.

The different results found by other authors and by this study may be associated to the variables used in the analysis. Also, the level of economic maturity of the countries, the time series observed and the methods of analysis can provide different results. Thus, this research topic offers a wide field for future research considering its importance for the individual economic processes of each country and the impacts on society.

\section{Final considerations}

This study aimed to analyze the relationship and the contribution of innovation as a driver mechanism of stock market performance and hence of the real economy in the case of China. The results showed a complete lack of consistent and systematic relationship between the indicative variables of The Global Innovation Index (GII), the stock exchange index (SSE Composite), and the Chinese macroeconomic performance (real GDP). As a result, it is possible to safely infer that none of the relations complies with the criteria established for this research, rejecting the hypothesis of the study, since changes in stock indexes would not be reflecting consistently and systematically in variations of the innovation levels (GII) and hence in the macroeconomic performance (GDP) of China.

In summary, it was not possible to consistently and systematically identify a relationship between technological innovation, economic growth, and the performance of the capital market able to describe and predict the behavior of these variables in the case of China. Thus, the study hypothesis was systematically rejected, which allows us to conclude that the performance of the capital market cannot serve as an economic indicator, since it wasn't found evidence that relate its performance with the evolution of economic growth and technological innovation. Therefore, a decrease in stock prices does not represent sufficient information to infer about the long-term economic growth behavior and of Chinese technological progress.

For further research, it is suggested to extend the analysis to other countries that have global economic importance, such as Japan and the United States. In addition, other variables could be incorporated in the analysis to give greater support to the results, such as the number of patents registered, among others. The incorporation of other variables can bring different results, as verified. For this reason, the same study can also be redone with the addition of new variables or other methods of analysis.

It is important to note the relevance of verifying the relationships between variables that may influence the macroeconomic performance of the countries. Understanding how innovation and the stock market are related to the total output of an economy is important not only in the theoretical field, but also from the practical point of view. Knowing the dynamics of these relations can contribute to formulate strategic actions in order to boost the countries' productivity, making these economies more competitive and raising the levels 
of social welfare of the population. Indeed, specific policies in the fields of innovation and the development of financial systems can be implemented, channeling investment and contributing to long-term growth and economic development.

\section{References}

Ahmed, A. D., \& Mmolainyane, K. K. (2014). Financial integration, capital market development and economic performance: Empirical evidence from Botswana.

EconomicModelling, 42, 1-14. doi:10.1016/j.econmod.2014.05.040

Araújo, B. C. (2013). Políticas de inovação no brasil e na China no século XXI. Rio de Janeiro: IPEA.

Badillo, E. R., \& Moreno, R. (2015) Ano está correto?.Does absorptive capacity determine collaboration returns to innovation? A geographical dimension. The Annals of Regional Science,volume?, número?, 1-27. doi:10.1007/s00168-015-0696-7

Burlamaqui, L. (2015). As finanças globais e o desenvolvimento financeiro chinês: um modelo de governança financeira global conduzido pelo Estado. In M. A. M. Cintra, E. B.Silva Filho, \& E. C. Pinto (2015), China em transformação: dimensões econômicas e geopolíticas do desenvolvimento(pp. ??).Rio de Janeiro: Instituto de Pesquisa Econômica Aplicada.

Carmo, C. A. (2011). BRICS: de estratégia do mercado financeiro à construção de uma estratégia de política internacional. Carta Internacional - Associação Brasileira de Relações Internacionais, 6(2), 03-15.

Cooray, A. (2010). Do Stock Markets Lead to Economic Growth? Journal of Policy Modeling, 32(4), 448460. doi:10.1016/j.jpolmod.2010.05.001

Deos, S. S. (2015). Sistema bancário chinês: evolução e internacionalização recente. In M. A. M. Cintra, E. B. da Silva Filho, \& E. C. Pinto (2015),China em transformação: dimensões econômicas e geopolíticas do desenvolvimento(pp. ??).Rio de Janeiro: Instituto de Pesquisa Econômica Aplicada.

Galindo, M.Á., \& Picazo, M.T. M. (2013). Innovation, entrepreneurship and economic growth. Management Decision, 51(3), 501-514. doi:10.1108/00251741311309625

Goldsmith, R. W. (1969). Financial structure and development. New Haven: Financial University Press.

Global Innovation Index. (2015). The Global Innovation Index. Retrieved from http:// globalinnovationindex.org/content.aspx?page=gii-home

Hair, J. F., Black, W. C., Babin, B. J., Anderson, R. E., \& Tatham, R. L. (2005). Análise multivariada de dados. Porto Alegre: Bookman.

Hicks, J. R. (1969). Theory of economic history. Oxford: Claredon Press.

Kuznets, S. (1966). O crescimento econômico do pós-guerra. Rio de Janeiro: Fundo de Cultura.

Lucas, R. E. (1972). Expectations and the neutrality of money. Journal of Economic Theory, 4(2), 103124. doi:10.1016/0022-0531(72)90142-1

Lucas, R. E. (1988). On the mechanics of economic development. Journal of Monetary Economics, 22(1), 03-42. doi:10.1016/0304-3932(88)90168-7

Mankiw, N. G. (2011). Macroeconomia. Rio de Janeiro: LTC.

Mendonça, A. R. R. (2015). Sistema financeiro chinês: conformação, transformações e controle. In M. A. M. Cintra, E. B. da Silva Filho, \& E. C. Pinto (2015), China em transformação: dimensões econômicas e geopolíticas do desenvolvimento(pp. ??). Rio de Janeiro: Instituto de Pesquisa Econômica Aplicada.

Modigliani, F., \& Miller, M. H. (1958). The Cost of Capital, Corporation Finance and the Theory of Investment. The American Economic Review, 48(3), 261-297. Retrieved from https://www.jstor.org/ stable/1812919 
Nonnenberg, M. J. B. (2010). China: estabilidade e crescimento econômico. Revista de Economia Política, 30(2), 201-218.

Organisation for Economic Co-operation and Development. (2005). Manual de Oslo: Diretrizes para coleta e interpretação de dados sobre inovação. Brasília: Finep.

Romer, P. M. (1986). Increasing returns and long-run growth. The Journal of Political Economy, 94(5), 1002-1037. Retrieved from http://www.journals.uchicago.edu/doi/pdfplus/10.1086/261420

Romer, P. M. (1990). Endogenous technological change. Journal of Political Economy, 98(5), 71-102. Retrieved from http://www.jstor.org/stable/2937632?origin=JSTOR-pdf

Schumpeter, J. A. (1951). Teoria do desenvolvimento econômico: uma Investigação sobre lucros, capital, crédito, juro e o ciclo econômico. São Paulo: Abril Cultural.

Shanghai Stock Exchange. (2015). Retrieved from http://www.sse.com.cn/

Shaw, E. S. (1973). Financial Deepening in Economic Development. New York: Oxford University Press.

Shen, C. H., \& Lee, C. C. (2006). Same Financial Development Yet Different Economic Growth - Why? Journal of Money, Credit and Banking, 38(7), 1907-1944. doi:10.1353/mcb.2006.0095

Silva, L. A. S. (2015). Desafios ao crescimento da China e implicações das alterações recentes na sua política cambial. Boletim de Economia e Política Internacional - BEPI, 20, 71-85.

Simonsen, M. H., \& Cysne, R. P. (2009). Macroeconomia (4a ed.). São Paulo: Editora Atlas.

Solow, R. A. (1956). Contribution to the theory of economic growth. The Quarterly Journal of Economics, 70(1), 65-94. Retrieved from http://www.jstor.org/stable/1884513?origin=JSTOR-pdf

Vieira, F. V. (2006). China: crescimento econômico de longo prazo. Revista de Economia Política, 26(3), 401-424.

Wonglimpiyarat, J., \& Khaemasunun, P. (2015). China's innovation financing system: Triple Helix policy perspectives. Triple Helix, 2, 02-18. doi:10.1186/s40604-014-0013-y

Zhang, J., Wang, L., \& Wang, S. (2012). Financial development and economic growth: recent evidence from China. Journal of Comparative Economics, 40(3), 393-412. doi:10.1016/j.jce.2012.01.001

Submetido em: 07/06/2017

Aceito em: 05/04/2019 